\title{
francisolât
}

\section{THE PLACE OF CODE-SWITCHING AS A MEDIUM OF INSTRUCTION IN LANGUAGE CLASSROOM IN GHANA: A CASE STUDY}

\author{
Theophile Kwame ATONON
}

\author{
Kwame Nkrumah University of Science and Technology, Ghana \\ attheokwa@yahoo.com
}

Article reçu le 28 septembre 2017 | révisé depuis le 29 septembre 2017 | accepté le 23 décembre 2017

\begin{abstract}
RÉSUMÉ. Dans le cas des langues en contact, l'emploi d'alternance codique par des enseignants et des apprenants devient un objet de discussion dans des institutions scolaires. L'objectif de ce travail est d'examiner le phénomène d'alternance codique en classe de français langue étrangère pour évaluer son influence sur l'enseignement/apprentissage du français langue étrangère dans le contexte ghanéen. Les données sont recueillis à travers l'observation des cours de français et les résultats sont analysés et représentés graphiquement. Les résultats ont montrés que l'alternance de code en classe de français langue étrangère promeut la communication et facilite l'interaction entre les enseignants et les apprenants. L'attention est prêtée au cas où le français est introduit pour la première fois en classe afin de faire ressortir des problèmes que font face les apprenants. L'alternance codique est donc important pour l'enseignement/ apprentissage du français langue étrangère et doit être inclus dans des programmes d'études de français au Ghana.
\end{abstract}

Mots-clés : alternance de code, interaction, langue étrangère, phénomène sociolinguistique, situation bilingue.

\begin{abstract}
In regard to languages coming into contact, the use of code-switching on the part of language facilitators and the learners has become an issue of discussion especially in the school setting. This paper sets out to examine critically the code switching phenomenon to ascertain its effects and necessity on the teaching and learning of French as a foreign language in Ghana. Data was collected through classroom observation while lectures were going on and the result was analyzed and represented in table form. The findings show that language switching in a classroom helps and supports the learning environment and makes it conducive for those involved. A careful consideration of code switching is done mostly at the level where the French language is introduced for the first time. The outcome of this paper suggests that code switching is important to the teaching and learning of French language and it must be adopted in our curriculum of studies.
\end{abstract}

Keywords: bilingual situation, code switching, foreign language, interaction, sociolinguistic phenomenon 


\section{INTRODUCTION}

Students in foreign language classroom face challenges of understanding and being able to speak fluently the language they studied and for that matter they do not show interest in studying the language. Despite the existence of different theories in the area of code switching among which one can mention (Poplack, 1981)'s model of code switching, there is little interest shown in the use of code switching in foreign language classroom.

Code switching is a socio-linguistic phenomenon which occurs mostly in bilingual communities. This phenomenon affects our ability to communicate our thoughts, emotions, and opinions to others in and around our environment. Considering the multilingual nature of Ghana, it is generally an observed fact that codeswitching has attracted a great scholarly attention in recent decades (e.g. (Flyman et Burenhult, 1999); (Yevudey, 2013);( AlgarinRuiz, 2014); (Senyatsi Khensani, 2012); (Youkhana, 2010). More specifically, (Yevudey, 2013) concluded that:

codeswitching should be considered as a teachable pedagogic resource, therefore, should be incorporated into teacher training syllabus and teaching methodology in Ghana. By so doing, teacher trainees will have knowledge of what codeswitching is, the types of codeswitching that could be used in the classroom, and the level at which codeswitching can be adopted to enhance teaching and learning. This would enable teachers to use codeswitching more purposefully and systematically in the classroom to achieve teaching and learning goals.(2010, p. 20).

Yevudey's work considered the relevance of code switching in the classroom and the findings show that code switching is very relevant in classrooms and it must be adopted as method of teaching in Ghana.

According to (Heller, 1988, p. 1) in (Youkhana, 2010, p.1), “code-switching is when a person mixes two languages in a single sentence or a conversation". On the other hand, Romaine (1992, p.110)) defined code switching as the "use of more than one language, variety, or style by a speaker within an utterance or discourse, or between different interlocutors or situations." This phenomenon of switching from one language to another language should be seen as a new method of explaining things in a classroom. This is because language teachers face a lot of challenges when introducing a new lesson in a foreign language class. Considering the level of understanding of the learners, it becomes very difficult to explain some topics in the language of instruction for easy understanding. This calls for alternation between languages in the form of code switching to aid the flow of ideas among teachers and learners.

Code switching must be a necessary method of instruction in a foreign language classroom regarding the numerous challenges facing both the teachers and the learners. A research on code switching in Ghana is very important in order to help reduce these challenges in classrooms.

Our main motive here is to find out how relevant is code switching in French language classroom in an Anglophone setting. Specifically, this study may serve as a guide to help develop a curriculum based on code switching in classrooms. If code switching is included in French language curriculum in our higher institutions, it can change the perceptions towards the study of French and encourage student participation and motivation in the classroom. The foreign language teachers can also adopt code switching as another method to enrich their teaching.

\section{MÉTHODE}

The investigation was made in three different lecture halls where students offer French as part of their courses in one of the universities in Kumasi, Ghana. The data for this study was collected through classroom observations and interviews. We chose to observe the various classes in order to listen to and watch what goes on in the classroom. Also about 20 students were interviewed they were observed when answering questions and discussing topics in class. The results of this research are analyzed and presented in the tables below. 
The major aim of this work is to find out the relevance of code switching; its usefulness and the end results to students in teaching and learning of French as foreign language. The main objective of this work requires two implications. The first implication would be how instructors can enhance instruction by using code switching as language enhancement tool in various classrooms more especially in tertiary institutions. In addition, it intends find out how it would support instructors in identifying the content areas which will meet the needs of students in studying a foreign language.

\section{RÉSULTATS ET DISCUSSION}

From our observations in the classrooms, the teachers from different classes observed find it difficult to teach without switching the code. For this reason they try to speak French but it was not helping the teaching and learning and this also delays the accurate delivery of the lecture. Those who don't want to switch the code appear to be under some kind of pressure and some even become frustrated.

The results from the classroom observation revealed that during their delivery, the teachers were using different types of code switching which were classified according to (Appel \&Muysken, 1987): inter-sentential code switching, extrasentential code-switching and tag switches

\section{Inter-Sentential Code Switching}

Inter-sentential code switching, according to (Appel \& Muysken, 1987, p.118), is the alternation in a single discourse between two languages, where the switching occurs after a sentence in the first language has been completed and the next sentence starts with a new language. It occurs within sentences as their names indicate. The teachers were using inter-sentential code switching because the students didn't understand the concepts introduced in the French language. Some examples were recorded below:

\footnotetext{
a. Orally you hear je vais faire pipi

b. Ask your friend tu as combien d'enfants?

c. He says je vais à Accra.
}

d. You can ask a friend où vas-tu?

e. J'ai un sac. He told Ama.

f. tell him, je suis étudiant.

From sentence (a) above the teacher was trying to explain a concept by switching the code for the learners to understand. As in (b) there was a conversation between the learners through which they were giving personal information. The pattern follows like that from sentences (c) through to (e). In this case the teacher wanted the learner to ask the friend a question in French. So he started the message in English before ending it in French. This type of code switching brings out another form of approach to help the learners understand what is going on in the classroom and the learning environment is made attractive and it motivates both the learners and the teacher.

\section{Intra-Sentential Code switching}

Intra-sentential code switching involves mixing two or more languages within the same sentence. In intra-sentential code switching, the shift is done in the middle or at the end of a sentence, with no interruptions, hesitations or pauses indicating a shift. The speaker is usually unaware of the shift. It is also the form of code mixing. Some or examples are recorded below:
a. When you go to boulangerie what do you buy?
b. Conjugation of verbs écouter, regarder, parler, être.
c. Next week we shall use the passé composé in sentences.
d. je vais à l'école is in present tense.
e. today we are going to study le passé composé.

Here the teacher was mixing the code in order to make the communication easy. In the case where the teacher uses only one code most especially when he uses French language throughout the understanding becomes very difficult. For instance if he said "la semaine prochaine nous ferons des phrases au passé composé" or "qu'est-ce que tu achètes à la boulangerie?" it was only few of them who could understand what it meant. The situation was the same in different classrooms that I went to. In some cases the teachers were forced to reduce the lesson to 
the level where learners can understand and participate in discussions. Some even use questioning and answering techniques to determine the level of understanding of the learners. This is also done in English language.

\section{Tag-switching}

There is an insertion of a tag from one language into an utterance that is in another language. For example: the situation where the teacher says "mais, you can't do that." Here, the tag "mais" is mixed in the English sentence.

Where the teacher said: "bon, do this for me". The term "bon" is a French tag which is used with English words. These codes are usually mixed during the lecture to help the students understand the concept being taught. Switching different codes serves as a tool which contributes to the achievement of the lay down teaching and learning outcomes and goals. Another situation when he said: "d'accord, try this at home". The tag "d'accord" is used together with English language. These may not be readily useful in explaining lessons but it can help the learner acquire new words or expressions in French.
It is observed that teachers switch code to draw the students closer and show them affection when the intention is to repeat the concept in order to explain what is being talked about and also socialize with others in the classroom. This attenuates the fear in the learners and this comes to support (Yevudey, 2013, p. 3), that code switching is useful for explaining and elaborating on concepts, increasing classroom participation, establishing good classroom relationships, ensuring the smooth running of the lesson, and making connections with the local culture of learners. Reducing the lesson to the level where students can understand and participate in discussions, questioning and answering questions motivate the students to learn. Through code switching the learning environment is made attractive and it also makes both the teacher and the students feel relaxed in the learning process

\section{Analysis of the questionnaires}

Q1. In which language is the lesson delivered during your lectures?

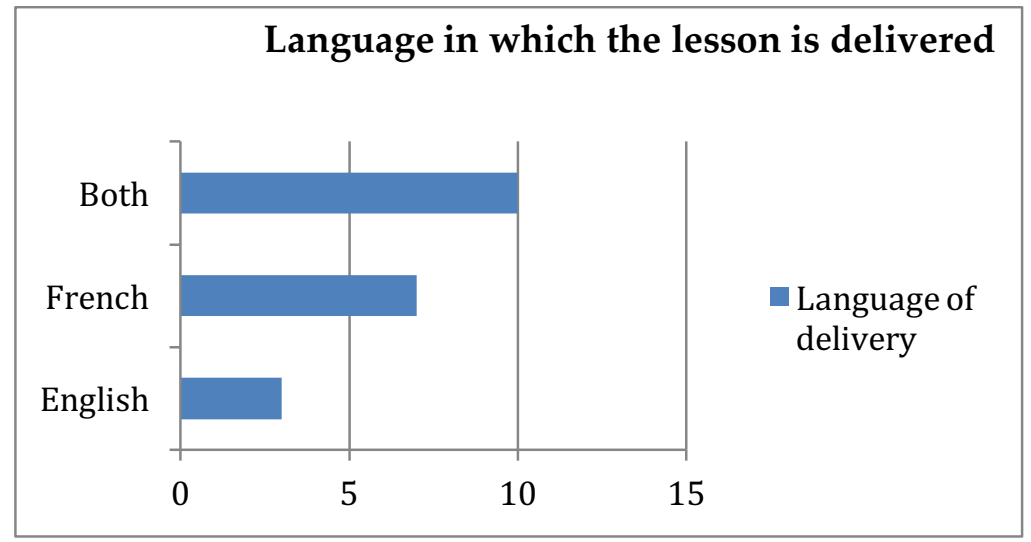

Figure 1. ( Language in which the lesson is delivered)

According to the answers given from the charts by about half of the respondents (50 percent), the lecturer uses both French and English languages in the delivery of the lesson; but to the other half of the class, the lecturer uses either only French or only English. Some (35 percent) think he uses more of French than English language and (15 percent) think he uses only English language. This response shows that the lecturer uses both languages in the lesson. In whichever way it is used, there are reasons why the lecturer changes the code in order to achieve learning outcomes.

Q2. How would you describe your attitude toward the switching of expressions from French to English? 


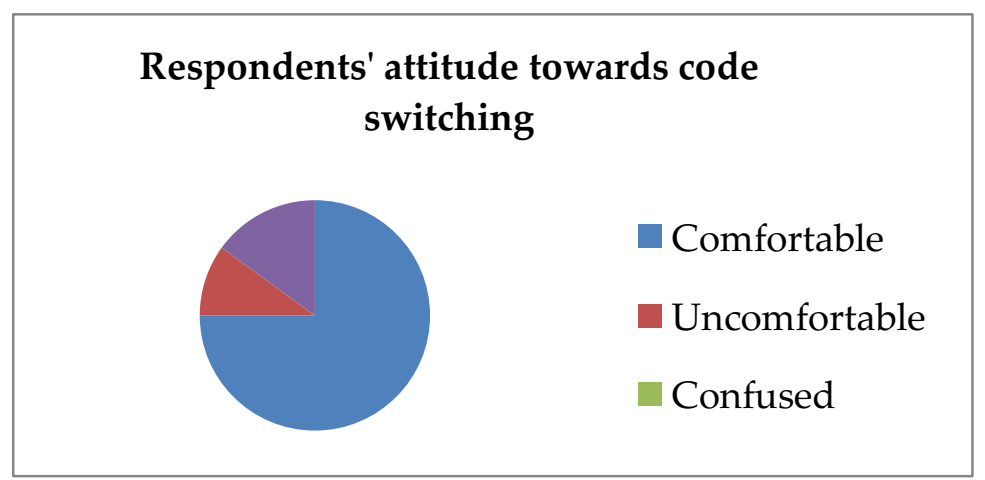

Figure 2. (Respondents' attitude towards code switching)

First and foremost, in the Fig.2 above are represented details of a quantitative analysis of the questionnaire survey on students' attitudes towards the foreign language classroom. We found out from the responses that 15 out of twenty totaling (75\%) feel comfortable in the class. While 2 of the respondents which is equivalent to $(10 \%)$ of the respondents, feel uncomfortable. Also, 3 of the respondents $(15 \%)$ were not sure whether they were comfortable with the code switching or not. All this while it is interesting to know that none of the respondent is confused when there is a switch of a code in the classroom.

According to the interview results, the respondents who feel comfortable and relaxed when the lecturer introduces the lesson in English said they easily assimilate the lesson. This is because they hardly understand and hear the French language. To them, many of them find it difficult to express themselves in the classroom just because they are afraid to say something which is wrong and for the fear of being given names by their colleagues, most of them prefer to remain quiet.
These actions, according to them, produce negative actions on their learning and understanding level. Some don't come to class because the class is very boring if only French language is used during the lesson and they don't understand anything. Some feel they are being discouraged instead of being motivated in the classroom by the use of purely French language. To some of the students, it is a hell for them due to that they have lost interest in the subject.

According to the respondents who feel uncomfortable when there is a code switch in the classroom, the motive behind the learning of French is to be able to speak it. But the frequent use of English language in the French classroom may not facilitate this idea. For this matter is will serve them good if the lesson is delivered only in French.

\section{Q3. Do you think that mixing French and English expressions in a language class should be encouraged?}

\section{Whether the Respondents think that code switching should be encouraged}

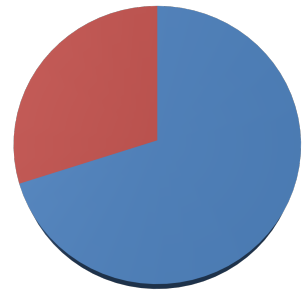

Not sure

Figure 3. (Whether the Respondents think that code switching should be encouraged) 
From Figure3. above, the students were asked, whether they would encourage codes witching during the lesson. The responses showed that $70 \%$ of the respondents expressed encouragement where $30 \%$ discouraged the use of code switching in language classrooms. This implies that majority are of the views that code switching should be motivated in the foreign language classroom to help create a conducive environment for them to meet their classroom needs.

The outcome of the interview shows that the students prefer the use of both English and French in the delivery of the lesson. Their reasons are that their level in French is poor for that reason if the lecturer speaks only French during the lesson they struggle to understand. Others said that they have never learnt French before so it will help them if there I balance in the use of both languages. To them many of the students are full time workers so they hardly get time to study. For this reason if the lesson is in English they will require a little effort to understand it. Some also prefer it in only French because this will challenge them to be focused and do more research to be able to understand the lesson. Some are with the view that when the lesson is in both languages they understand the lesson but cannot express themselves in French. For some they are learning for communication purposes so the use of only French and mimic signs will help them.

Performing code switching in the classroom may create problems for the students. As they will be limited in speaking French and they cannot recall the appropriate grammatical structure taught in French. It may be claimed that this type of language alternation may have negative effects on learning a foreign language; since it may result in loss of fluency in long term.

Another explanation for the relevance of code switching in classroom is to transfer the needed knowledge to the students in order to clarify meaning and to stress on the topic being taught. However, the tendency to repeat the instruction in native language may lead to some undesired student behaviors. A student who is sure that the instruction in
French language will be followed by English language translation may lose interest in listening to the former instruction which will have negative academic consequences; as the student is scarcely exposed to discourses in French language.

\section{CONCLUSION}

To conclude, code switching is a phenomenon that is inevitable in bilingual situations. It occurs mostly in places where languages come into contact. Although it is a phenomenon that may be considered incompetent in languages, it is natural, and can be turned to a purposeful and useful activity in language classes if it is accepted and adopted as a medium of instruction. It occurs mostly to create a kind of connection which will lead to understanding in the discourse.

Code switching as a teaching aid must be recommended to be part of the practices in educational programs today especially where the student has to depend on prior knowledge to learn new information. It promotes a positive environment in the classroom by allowing students learn new words, phrases or terms while depending on their previous knowledge and interaction among their peers.

Educators need to research into the area of code switching in foreign language classroom and encourage its use in classroom to facilitate understanding and to reverse controversy in the choice of teaching method in foreign language classroom. What we must not forget is that the main purpose of studying language is to be able to communicate. Any method that can facilitate communication in that regard should be encouraged. The code switching should be used especially while teaching new vocabularies and introducing new topics.

We have pointed out from this work the advantages of the use of Code switching which is to improve up on the understanding and create an affective environment for both the speaker and the hearer. Code switching, therefore, becomes useful in a multilingual society most especially in foreign language classroom to help the learners understand and develop some kind of love for the 
subject. The positive effects of the use of code switching in the classroom situation are also discussed, based on the responses provided, to explain why the phenomenon of code switch is important. Code switching may be viewed as detrimental to the activities in the classroom but its positive functions outweigh the negative functions therefore it can be incorporated into language curriculum. It must therefore be taken as one of the main teaching strategies in the language classroom interactions. When code switch is adopted in the classroom environment, it may help the transference of knowledge to students and provides understanding so as to bring efficiency.

However, in the case of French language studies the instructors should control the use of the code switch in order to help communication in the French language. Since one major reason for studying a language is to be able to communicate, there must be appropriate environment for easy understanding.

\section{REMERCIEMENTS}

My sincere appreciation goes to Seth Afari for accepting to read this work through and give the necessary recommendations. I thank all my colleagues and friends for their words of encouragement and advice to push this idea into reality. I also give thanks to my family most especially my wife and my daughter for being there for me all the time.

\section{RÉFÉRENCES}

Appel, R. \& Muysken, P. (1987). Language Contact and bilingualism. London: Edward Arnold.

Flyman-Mattsson, A., \& Burenhult, N. (2009). Code-switching in second language teaching of French. Working Papers in Linguistics, 47, 59-72.

Romaine, S. (1992). Bilingualism. Cambridge: Blackwell Publishers.

Yevudey, E. (2013). The pedagogic relevance of codes witching in the classroom: insights from ewe-English codes witching in Ghana. Ghana Journal of Linguistics 2.2: 1-22 (2013).

Youkhana, S. (2010). Code-switching in the foreign language classroom. Höstterminen. Engelska, 15, 61-90. 